\title{
The quest for ecological tax reform : a Schumpeterian approach to public finance
}

\author{
Citation for published version (APA):
}

Backhaus, J. G. (1995). The quest for ecological tax reform : a Schumpeterian approach to public finance. METEOR, Maastricht University School of Business and Economics. METEOR Research Memorandum No. 009 https://doi.org/10.26481/umamet.1995009

Document status and date:

Published: 01/01/1995

DOI:

10.26481/umamet.1995009

Document Version:

Publisher's PDF, also known as Version of record

\section{Please check the document version of this publication:}

- A submitted manuscript is the version of the article upon submission and before peer-review. There can be important differences between the submitted version and the official published version of record.

People interested in the research are advised to contact the author for the final version of the publication, or visit the DOI to the publisher's website.

- The final author version and the galley proof are versions of the publication after peer review.

- The final published version features the final layout of the paper including the volume, issue and page numbers.

Link to publication

\footnotetext{
General rights rights.

- You may freely distribute the URL identifying the publication in the public portal. please follow below link for the End User Agreement:

www.umlib.nl/taverne-license

Take down policy

If you believe that this document breaches copyright please contact us at:

repository@maastrichtuniversity.nl

providing details and we will investigate your claim.
}

Copyright and moral rights for the publications made accessible in the public portal are retained by the authors and/or other copyright owners and it is a condition of accessing publications that users recognise and abide by the legal requirements associated with these

- Users may download and print one copy of any publication from the public portal for the purpose of private study or research.

- You may not further distribute the material or use it for any profit-making activity or commercial gain

If the publication is distributed under the terms of Article $25 \mathrm{fa}$ of the Dutch Copyright Act, indicated by the "Taverne" license above, 
revised, May 8, 1995

THE QUEST FOR ECOLOGICAL TAX REFORM:

A Schumpeterian Approach to Public Finance

by

\author{
Jürgen Backhaus ${ }^{1}$ \\ Rijksuniversiteit Limburg \\ Faculty of Economics and Business Administration \\ P.O. Box 616 \\ 6200 MD MAASTRICHT \\ The Netherlands \\ Phone: 043-883636
}

Fax: 043-258440 
Paper prepared for presentation at the Fifth Conference of the International J.A. Schumpeter Society

on

Economic Dynamism: Analysis and Policy

Münster, Germany, August 17-20, 1994 


\section{ABSTRACT \\ THE QUEST FOR ECOLOGICAL TAX REFORM:}

A Schumpeterian Approach to Public Finance

Recent quests for ecological tax reform are difficult to evaluate from an economic point of view, as they typically are based on an interdisciplinary argument drawing on contributions from biology, systems theory and economcis. In order to create a framework for reference and analysis, this paper sets out Henry George's theory with respect to the natural environment. The environment is shown to be the very broad and potentially productive tax base for George's Single Tax constitution. The tax constitution is shown to be a selfenforcing one, checking public sector growth by linking it to material progress in the economy. Also, the Georgist tax constitution is shown to provide incentives for an optimal use of environmental resources in the interest of both present and future generations.

Disregarding the controversial case for a Single Tax for the moment, the remainder of Henry George's framework can very well serve to evaluate ecological taxes in terms of their main objective, i.e. to ensure sustainable economic development. The paper argues that a more convincing case for ecological taxes can be made if that case is based on Georgist precepts.

JELcode: B 13, H 21, Q 28, Q 38 
THE QUEST FOR ECOLOGICAL TAX REFORM

\section{A SCHUMPETERIAN APPROACH TO PUBLIC FINANCE}

\section{Introduction}

Ecological tax reform is on the political agenda of most Western European countries today. Even the European Community is seeking to introduce ecological charges. Although purely fiscal i.e. revenue seeking motives certainly explain part of the political impetus, the ecological taxes present a specific class of revenue instruments which present political but, for the purpose of this paper more importantly: analytical issues different from standard taxes discussed in public finance textbooks. The differences relate to three issues or dimensions, the combination of which renders ecological taxes as typically proposed an extremely complex and potentially harmful instrument, which may not easily fit into the general tax structure of known fiscal regimes. Under these circumstances, it is sensible to evaluate ecological taxes from the point of view of a simple bench mark alternative, which nevertheless is not consistent with the basic purpose of the proposed ecological taxes. Since ecological taxes have a particular purpose, i.e. the prudent use of the natural environment in general and certain energy sources in particular, and since unlike Pigouvian charges they are not necessarily supposed to be fiscally infertile, i.e. they may very well generate a substantial revenue, the bench mark case can neither be the classical tax raised for purely fiscal purposes, nor the Pigouvian charge raised in order to correct for market failure. Rather, a third bench mark needs to be chosen. This is where Henry George comes in. Henry George has many admirers, but only a few scholarly economists would regard him as one of their own. In this paper, I argue not only that Henry 
George made a sound contribution to political economy; I also claim that his analysis is eminently significant for environmental economics today, and in particular for an evaluation of current proposals for ecological charges. This evaluation is meant to be critical and constructive.

The subtitle of this essay perhaps requires a word of explanation. Schumpeter is less well known for his public finance contributions (but see Backhaus 1994), his contributions almost never being mentioned in modern public finance text books. ${ }^{2}$ The strength of Schumpeter's approach to public finance lies in his ability to analyse entire economic systems as they are confronted by complete structures of taxation and public spending. He pioneered what is today called constitutional public finance, and his approach is therefore particularly apt for an analysis of suggested new tax institutions such as ecological taxes.

The paper starts with a short characterization of the typical case of ecological charges. It highlights the three characteristics mentioned above. The paper then proceeds with a short presentation of George's biography and offers a brief characterization of his approach to economic analysis. The next three sections are in turn devoted to the focus of his analysis, viz. natural resources, the tax constitution envisaged, and the implications of this tax constitution for environmental policy. The final section (VI) offers a few general conclusions on the importance of Georgist thought for environmental economics and the more specific conclusions with respect to the case for ecological taxes. 
The most eloquent case for ecological tax reform has perhaps been made by Ernst Ulrich von Weizsäcker in various publications (e.g. von Weizsäcker and Jesinghaus, 1992). The case is obviously made by natural scientists, and it is made in terms of a natural science argument, not in terms of an economic argument or an argument in the tradition of public finance analysis. $\mathrm{CO}_{2}$ emissions are contrasted with population growth, and the extreme (sometimes exponential) growth of both these magnitudes lies at the heart of the case for containing $\mathrm{CO}_{2}$ emissions in order to achieve a (biologically) sustainable economic growth. The chief variable then is also biologically defined, although at first glance it looks like an economic variable.

" $\mathrm{CO}_{2}$ productivity may (and here we are disregarding the fact that GNP is a measure of turnover, not prosperity) be broadly defined as one unit of GNP per unit of $\mathrm{CO}_{2}$. (von Weizsäcker and Jesinghaus, 1992, p. 10).

The purpose of ecological taxes is then to increase $\mathrm{CO}_{2}$ productivity as defined above.

Although the most important increases in future $\mathrm{CO}_{2}$ emissions have to be expected outside the highly developed Western and East-Asian countries, the case is still made for employing ecological taxes in those very countries as they are supposed to be much better equipped to technologically respond to the imposition of such taxes. This is an important assumption about the adaptability of these economies consequent to imposing ecological taxes which will not further be questioned. 
Three characteristics of this approach stand out in contrast to the mainstream of received tax theory. The first and most stunning characteristic is the peculiar purpose of ecological taxes. While they also are expected to generate revenues, the most important aspect is to reduce the use of particular parts of the natural endowment (in energy sources) with a view to employing them most productively. However, the notion of productivity is not defined as it would have to be in order to make an economic case for the ecological taxes. $\mathrm{CO}_{2}$ productivity is defined in terms of relating physical inputs to market valued outputs, i.e. the measure is defined in terms of two different dimensions. We then have two purposes with two different dimensions, the achievement of revenues for the public purse which is measured in market based units, and the achievement of natural resource productivity as measured by a composite of physical and market based values. This discongruence results in a third characteristic of ecological tax reform proposals which is inherent in the methodology but troublesome from the public finance point of view. In public finance, a case for a particular tax can be made when the benefit from taxation (typically measured in social welfare terms) exceeds the direct resource cost of the tax plus the excess burden imposed on the economy by raising the tax. All three magnitudes are measured in market based terms, and are therefore easily comparable. Ecological taxes are different in that they cannot easily be subjected to a test in terms of their welfare implications. By necessity, the welfare cost of their imposition in terms of both the welfare foregone as a consequence of reducing natural resource use and the cost imposed as a consequence of administering the tax have to be neglected, as they cannot be measured. The neglect of the welfare costs of environmental taxation which has been built into the interdisciplinary methodology can have serious consequences for their practical applicability. The welfare losses will, of course be experienced by people who in turn will express this experience in the political process and thereby conceivably derail the entire ecological program. It is in this sense that the interdisciplinary methodology may result in a utopian program eventhough the espired 
goals might be utterly realistic. Although the purpose of the ecological tax seems to be very much in congruence with Henry George's objective of obtaining the most prudent use of natural resources, George does not add the additional problem of incongruous dimensions which somehow makes the case for ecological tax reform difficult to maintain in economic terms. Let us therefore take a look at Henry George's approach in order to determine whether it could yield a more defensible case for ecological tax reform.

\section{II}

Henry George (1839-97) was a self-taught American economist and political writer whose name is commonly associated with the notion of a Single Tax on land. George had worked as a sailor, printer and newspaperman when he became fascinated with the rapid and uneven development of California and began to probe the economic causes determining the price of land. This investigation he undertook in order to solve "the great enigma of our times", which he held to be "the association of poverty with progress" (1979, p. 10). His insights he systematically developed in his Progress and Poverty, first published in $1879 .{ }^{3}$ The book began to receive wider attention in Britain in connection with the Irish question and later made George famous in his own country, too. He spent the last part of his life as a public speaker at home and abroad, and it was George himself who made the Single Tax proposal a political issue in his (unsuccessful) bids for the mayoralty of New York first in 1886 and again in 1897.

His place in the history of economic analysis is aptly sketched by Joseph Alois Schumpeter who writes: 
"The points about him that are relevant for a history of analysis are these. He was a self-taught economist, but he was an economist. He acquired most of the knowledge and of the ability to handle an economic argument that he could have acquired by academic training as it then was. In that he differed to his advantage from most men who proffered panaceas. Barring his panacea (the Single Tax) and the phraseology connected with it, he was a very orthodox economist and extremely conservative as to methods. They were those of the English 'classics', A. Smith being his particular favorite. [...] Even the panacea - nationalization not of land but of the rent of land by a confiscatory tax - benefitted by his competence as an economist, for he was careful to frame his 'remedy' in such a manner as to cause the minimum injury to the efficiency of the private-enterprise economy. [...] The proposal itself $[\ldots]$ is not economically unsound, except in that it involves an unwarranted optimism concerning the yield of such a tax. In any case, it should not be put down as nonsense. If Ricardo's vision of economic development had been correct, it would even have been obvious wisdom." (1954, p. 865).

Schumpeter was correct in characterizing George's economic methods as conventional. Yet Progress and Poverty is not mainly a work of economic analysis, but a decidedly unorthodox and non-conservative social reformer's treatise. The book was written in order to provide the answer to a practical question of economic policy: How can we design an institutional order in which economic progress goes hand in hand with a reduction of poverty? Schumpeter, like many other critics of George, probably was incorrect in casually dismissing George's assertion about the practical possibilities of George's tax constitution from the standpoint of revenue yield. George may very well have been justified in his optimistic estimate of the yield of his Single Tax. This tax is a far cry from the real estate taxes a superficial reader may associate 
with the term "tax on land". Rather, as I try to explain on the following pages, George presents us with a comprehensive package of an environmental tax reform which, politically, has teeth. The program is, in fact, a tax constitution so comprehensive and far-reaching that no attribute could be more misleading than the term "conservative".

As this author reads Progress and Poverty, George comes across as a scholar in the best tradition of political economy. His analysis is motivated by a clearly defined social policy problem. George analyzes a problem in order to solve it. He succeeded in designing a solution - his "remedy" - which relies on an institutional reform, i.e. George understood the interdependence between economic processes and the institutional order in which they take place. Finally, George went about his analysis in what today would be described as an interdisciplinary approach, $\underline{\text { i.e. }}$ the questions he would consider were forced upon him by the subject matter under consideration and not by some disciplinary boundaries as they might have developed over time. When, e.g. he looks at the effects of his "remedy", he takes them up in this order: effects on (1) production, (2) distribution, (3) individuals and classes, and (4) social organization and social life (1979, IX).

III

The shortest book in Progress and Poverty, and at the same time the most important, is book VI in which George spells out his program. The central chapter, entitled "The True Remedy" 
barely covers two printed pages, and the solution itself is stated in just one sentence: "We must make land common property" (1979, p. 328).

The explosive potential of his program is wrapped into this rather innocuous sentence. The true extent of the proposal can be discerned by looking at the implementation rule and his concept of land. The implementation rule is stated in equally concise terms: "It is not necessary to confiscate land, it is only necessary to confiscate rent" $(1979$, p. 405). Finally, there is an underlying principle also worth reporting: "What is necessary for the use of land is not its private ownership, but the security of improvements" (1979, p. 398). This quote also points to Henry George's differentiation between improved and unimproved natural resources and the idea of the unearned improvement. The unearned improvement today turns out to be a hindrance to improvements tomorrow, since the possibility of gaining unearned improvements diverts energies from the very process of improving upon natural resources. In contemporary language, one might say that George tried to prevent wasteful rent-seeking activities by insisting on the principle that the benefits from improvements should accrue to whoever made the improvements, whereas unclaimable externalities belong to the common domain.

The purpose of the entire reform program, according to this principle, is to encourage the use of land by designing a structure of property rights which allows individuals to reap the benefits of their labor, viz. the 'improvements' without barring the use of common property resources by others. His definition of 'land', as spelled out in a chapter appropriately entitled "The Meaning of the Terms" (1979, p. I 2) is not confined to the surface of the earth. His is an analytical definition based on the concept of factors of production. There are in George's model two original factors of production, called 'labor' and 'land'. 'Capital' is a secondary or derived factor of production, comprising only things "which have resulted from the union of 
these two original factors of production" (1979, p. 39). Since 'labor' is defined in a more standard way as "all human exertion", including, by the way, 'human capital', because "human powers, whether natural or acquired can never be classed as capital" (1979, p. 39); this leaves land as the all encompassing category of those original means of production which are not labor. In short, 'land' stands for the endowment of natural resources.

Characteristically, George defines land both analytically and by giving a sequence of examples illustrating the basic, comprehensive concept:

"The term land necessarily includes, not merely the surface of the earth as distinguished from the water and the air, but the whole material universe outside of man himself, for it is only by having access to land, from which his very body is drawn, that man can come in contact with or use nature. The term land embraces, in short, all natural materials, forces, and opportunities, and, therefore, nothing that is freely supplied by nature can be properly classed as capital. A fertile field, a rich vein of ore, a falling stream which supplies power, may give to the possessor advantages equivalent to the possession of capital, but to class such things as capital would be to put an end to the distinction between land and capital, and, so far as they relate to each other, to make the two terms meaningless." (1979, p. 38).

It is obvious that, commensurate with technical progress, the window of opportunities granted by nature is pushed ever more open, and in this way the Georgian term 'land' assumes an ever more encompassing meaning. Simultaneously, the tax base of the State entrusted with the power of the Single Tax on the rent of natural resources is also broadening in pace with 
technical progress. While George defines 'land' in exactly the same way as we define natural resources today, George differs from most present-day proponents of environmental tax reform by wishing to encourage the prudent use of natural resources, whereas the standard approach today is to design schemes seeking restriction of such use.

Henry George's definition of land clearly includes also natural resources beyond land and certainly also energy resources. The application of the term goes ever beyond this, however, in that it can also include collectively used natural resources, such as the oceans, the air, even the climate. This aspect points to a wider applicability of George's approach than is usually suggested. It is here where the potential for applying George's approach to the issue of ecological taxes comes in.

IV

The twin objective to open access to the use of all opportunities provided by the natural environment while, at the same time, granting full security of all improvements made upon the resource as found in the state of nature requires a partitioning of property rights along this distinction. This partitioning ${ }^{4}$ must have struck many of George's contemporaries as unusual or artificial. But, as he tries to show in his long survey of "Property in Land Historically Considered" (1979, VII 4), the partitioning should not be considered that unusual after all. You don't saw a ship in half if it is owned by two men, is his common sense comment. ${ }^{5}$

The partitioning of property rights is effected through the instruments provided by the modern tax state. Owners retain their property titles, but these titles are re-interpreted as designating the accumulated improvements, while the entire land rent remains in the common property 
of the state. The tax state, in this way, becomes a partner in the development of the land (country), a residual claimant of all the external benefits not appropriated by the individual owners. Since this point is very important for understanding the dynamics of the Georgian scheme, let us look at his own statement:

"Every productive enterprise, besides its returns to those who undertake it, yields collateral advantages to others. If a man plant[s] a fruit tree, his gain is that he gathers the fruit in its time and season. But in addition to his gain, there is a gain to the whole community. Others than the owner are benefitted by the increased supply of fruit; the birds which it shelters by far and wide; the rain which it helps to attract falls not alone on his field; and, even to the eye which rests upon it from a distance, it brings a sense of beauty." (1979, p. 435).

Assigning the unappropriable positive externalities of production to the State implies that George's concept of common property in natural resources actually goes even beyond the original state of nature. It likewise includes the accumulated externalities or, put in more accessible terms, the cultural heritage of a country, its vegetation, climate, architecture and landscape, etc.. And, by virtue of the tax scheme, this cultural heritage also forms the tax base which the state is expected to foster.

"Nature laughs at a miser" (1979, p. 436), Henry George tells us in characteristic prose, and he certainly laughs at too parsimonious a use of the natural endowment. Not only is the tax scheme designed to minimize disincentives (1979; IX 1); stronger still, it co-erces people into either making productive use of the resources they possess or else relinquishing them: "If land were taxed to anything near its rental value, no one could afford to hold land that he was not 
using" (1979, p. 413). As Von Weizsäcker and Jesinghaus suggested, the purpose of making the most productive use of an environmentally based energy source is completely consistant with Henry George's approach. However, productivity in George's terms is measured in such a way that the economist can make use of it. As a consequence of the tax levied on natural resources, irrespective of whether they are used or not, the user has to make the most productive use of the natural resource made available to her, and this use has to be made in such a way that the source is not being depleted.

This growth oriented fiscal constitution, however, has a clever check on public sector growth built into it. It is here where the seemingly ideological and often misunderstood insistence on the Single Tax assumes importance. This feature of the Georgian proposal has always bewildered so many commentators, including the public finance expert ${ }^{6}$ Schumpeter. The explanation lies in the systematic unity of George's proposal. George suggested a tax constitution which defines incentives faced by the tax collecting authorities. George wanted to foster progress by using the power to tax in a very specific way, but he was also suspicious of government bureaucracies (1979, VIII 3). By designating a broad tax base but limiting the power to tax to just one tax, the tax of up to $100 \%$ on the rent of natural resources, he hoped to find the proper balance. On the one hand, the Georgian tax constitution creates incentives for those in public office to support equitable economic development, which flushes ever increasing tax revenues into public coffers. The State can grow unimpeded by any pre-conceived restrictions, as long as this public sector growth is financed from the increasing rental value of natural resources. On the other hand, as soon as the value of these rents stagnates or even declines, the state has to curtail its own expenditures. By virtue of the Single Tax constitution ${ }^{7}$, the State is harnessed into prudent, long term natural resource use, just as the private sector is coerced into attaining the production possibility frontier. Built into 
George's reform is a 'tax constitution for Leviathan', to use Buchanan's term, a public choice approach avant-la-lettre. In one respect, however, George's tax constitution is different from the typical Leviathan tax constitutions which we owe to the modern public choice school. The limits on the size of the state budget are not predetermined, but determined according to the tasks the state may face. For instance, as natural resource use creates negative externalities, to the same extent it increases the claim of the state on financial resources to mitigate these effects. On the other hand, if nature is left in a pristine state, the state's claim on financial resources is very limited indeed; but so are the state's tasks in such an economy.

\section{V}

Even more surprisingly, this growth-oriented tax constitution clearly deserves the label "environmental" due to its built-in dynamic structure. By an "environmental" or "ecological" tax scheme one understands a fiscal constitution which induces economic agents to make optimal use of the environmental resources, neither squandering nor oversparing them. This is precisely what the Georgian system is designed to accomplish. The clue to the conservational feature of the Georgian tax constitution, again, lies in the partitioning of property into (internalizable) improvements (private ownership) and the rent of the resource as such (public ownership). The size of this rent is a positive function of the state of economic development of the surrounding economy and a negative function of the exhaustion of the natural resource. Obviously $^{8}$, the rent on resource use is paid exclusively for the use of the natural endowment and not for its abuse. Depletion of a natural resource requires an additional compensation owed to the community which, in the Georgian model, is represented by the Tax State. The State is thereby entitled to two streams of revenues, viz. the rent collected from the use of its natural resources and, more generally, the environment; and the compensations for the abuse of those 
resources. Clearly, George was not a strict conservationist in the sense of sparing nature from any form of depletion. He wanted the ore to be mined and not to be left in the ground (1979, p. 38). Yet, at the same time, he wanted the community to extract a fair compensation for this impairment. While the guarantee of improvements is the core of the State guarantee of private property rights, impairments of common property resources require a compensation. The State thereby can plan the inter-temporal use of the natural resource endowment in the interest of overall fiscal concerns.

The operational coherence and conclusivity of the abuse correction mechanism, of course, needs to be spelled out in institutional detail. Much will depend on the particular tax administration a country has set up. Such an administration would have to be backed by a system of tax courts in such matters as when judgement is required as to when an action constitutes an abuse or not. ${ }^{9}$

This inter-temporal dimension embedded into Henry George's tax constitution assumes additional importance when we consider the change or reversal of uses environmental resources may be put to. Keeping the door to change and, notably, changes in resource use wide open is vital for preventing the rise and persistence of monopolies. The Georgian scheme, of course, requires that every resource be put to its most productive use. Again, the dynamic adjustment process is carefully conceived. The most productive use determines the rent of the resource, irrespective of whether the owner operates at the production possibility frontier or not. The automatic adjustment of rents, as a consequence of technical progress, constantly pushes economic agents to make the most judicious use of environmental resources. This implies that the Georgian system actually encourages the reversal and change of production methods involving natural resources. Unlike the present system of private property in land (1979, p. 
VII 5), the scheme does not favor the first user at all, since a more valuable use makes it too expensive to continue the first use. The opportunity costs of natural resource use, by virtue of the land rent tax, enter into the present user's cost function.

Reversal of use can be more vexing a problem if natural resources are irretrievably devoted to some production (or consumption) process. The safeguard provided by the Georgian system is not a perfect one, since George opposed the conservation of natural resources for their own sake. Yet, George provided for two checks. The irreversible use of an environmental resource is checked on the one hand by the compensation payment required for abuse. The amount of this payment, in turn, will increase with the introduction of competing, more valuable uses as a consequence of technical progress. The second check lies in the communal nature of environmental resources. Since the environment is in the common property i.e. State domain, a political decision can override private commercial concerns. The political decision will be informed, above all, by the revenue consequences for the Single Tax State, a State which George has placed in the position of guardian of the environment in order to ensure its own fiscal survival.

This paper sets out Henry George's theory with respect to the natural environment. The environment is shown to be the very broad and potentially productive tax base for George's Single Tax constitution. The tax constitution is shown to be a self-enforcing one, checking public sector growth by linking it to material progress in the economy. Finally, the Georgian tax constitution is shown to provide incentives for an optimal use of environmental resources in the interest of both present and future generations. 
In terms of evaluating Henry George's contribution from today's point of view, what stands up is the overall focus on designing a self-enforcing tax constitution on natural resources which is clearly embedded into an otherwise wildly flowering prose which is quite apt to side track the modern reader. As the reader can gauge from the first footnote, George was very eager to see his book in print, not because of professional vanity - he was not a professional economist; but because of his feeling that the proposed "remedy" was the corner stone of an attractive political program. As a politician, Henry George was largely proven wrong so far.

The basic differences then between Henry George's approach to ecological taxation and the current proposals for ecological taxes are two:

On the one hand, by making the use of every type of natural resource taxable, but completely exempting the improvements, Henry George puts forth the most ecologically minded tax system that is conceivable.

Secondly, by also taxing any type of impairment, Henry George builds in a differential incentive discriminating against energy use that is either non-sustainable or involves the creation of negative externalities.

\section{REFERENCES}


Backhaus, J. 1988. "Justiziable Bedarfsprüfung im Genehmigungsverfahren: ein Lüneburger Vorschlag", in: Jörg Finsinger and Jürgen Simon (eds.) Recht und Risiko, VVF, Munich, 94112.

Backhaus, J., Krabbe, J. 1991/1992. "Henry George's Contribution to Modern Environmental Policy", American Journal of Economics and Sociology. 50 (4), pp. 485-501; 51 (1), pp. 1-18.

Backhaus, J. (1994), "The Concept of the Tax State in Modern Public Finance Analysis". In Mark Perlman (ed.), ... an Arbor: University of Michigan Press 1994.

Furubotn, E. 1979. "Codetermination and the Efficient Partitioning of Ownership Rights in the Firm", Journal of Theoretical and Institutional Economics 135, 2, 207-215.

George, H. 1979. Progress and Poverty: An Inquiry into the Causes of Industrial Depressions and of Increase of Want with Increase of Wealth ... The Remedy. Robert Schalkenbach, New York.

Schumpeter, J. 1954. History of Economic Analysis. Oxford University Press, New York.

Wagner, R.E. 1983, Public Finance: Revenues and Expenditures in a Democratic Society. Boston Little, Brown and Company

Weizsäcker, E., von, Jesinghaus, J. 1992. Ecological Tax Reform: A Policy Proposal for Sustainable Development. London: Zed Books. 


\section{ENDNOTES}

1 The author should like to thank Nicolaus Tideman for helpful comments

2 The only exception to my knowledge is Wagner 1983, $245-247$

3 Progress and Poverty was first published by D. Appleton \& Co. in New York in January, 1880. However, in his preface, George refers to the November 1890 edition already as the fourth. His account of the editorial history is as follows: "This work was written between August, 1877, and March, 1879, and the plates finished by September of that year. Since that time, new illustrations have been given of the correctness of the views herein indicated [...]. But there has been nothing in the criticisms they have received to induce the change or modification of these views - in fact, I have yet to see an objection not answered in advance in the book itself. And except that some verbal errors have been corrected and a preface added, this edition is the same as previous ones." (1979: p. xxx).

A twenty-fifth anniversary edition with a preface by Henry George jr. was published in 1905. The son explains that the publisher had insisted on George bearing the cost of making the plates, which George did in the shop of a friend in San Francisco. There, "an 'Author's Proof Edition' of five hundred copies was struck off" (1979: p. xxiii). A centenary edition prefaced by his grandaughter, Agnes George de Mille, appeared in 1979 in New York, published by the Robert Schalkenbach Foundation. This 1979 edition contains the aforementioned prefaces as well as an extensive index and a glossary of terms.

In conclusion, the first edition was San Francisco 1879, the first published edition New York 1880, and the final authorized edition with any changes New York 1890 (4).

For a modern statement see Eirik G. Furubotn, 1979. 
An anonymous referee has pointed to the difficulty of measuring what part of the "unearned" increment is due to nature, what part due to society, and what part due to entrepreneurship or effort. Dr. Krabbe and I have dealt with this issue elsewhere and at length. (See Backhaus and Krabbe, 1991/1992).

6 The welfare theoretic aspects of the capital single Tax have been dealt with in a separate paper, see Backhaus, "Henry George and the Environment", Journal of the History of Economic Thought, Spring 1991. 13.1, pp. 90-98.

7 This modern language should not lead the reader to suspect that the single tax might be without problems. It is conceivable that the single tax might not be Pareto optimal, notably because of effects on the timing of development. But one should keep in mind that George was making a contribution to economic policy, and not to the theory of optimal taxation. Even in the case of suboptimality just mentioned, one has to keep in mind that these cases require resort to second best analysis, and that it is by no means inconceivable that the lest distorting tax regime in the world of second best remains the single tax.

8 The following paragraphs are not literally grounded in Henry George's Progress and Poverty; they follow directly from his definition of land as including all natural resources and his definition of improvements. But he did not himself spell out these implications, nor did he spell out details of the requisite implementation rule.

9 For the United States, one can start thinking about such procedures by looking at the reclamation of land used for surface strip mining. See US Surface Mining Control and Reclamation Act of 1977, (P.L. 95-87). This law calls for bonding and specifies landscape contours, vegetation, etc. For Germany, an actionable procedure has been described in Jürgen Backhaus, 1988. 